\title{
Joanna Sakowicz
}

Warszawa

\section{Zamach na prezydenta Johna F. Kennedy'ego na łamach prasy polskiej $z$ lat 1963-1964}

Mimo iż od zabójstwa prezydenta Johna Fitzgeralda Kennedy'ego upłynęło ponad 40 lat, jego okoliczności wciąż budzą wiele kontrowersji. Nagła, tragiczna śmierć prezydenta zapoczątkowała falę dyskusji na temat motywów i sprawców zbrodni nie tylko w samych Stanach Zjednoczonych. Celem niniejszego artykułu jest przedstawienie pozamachowej kampanii prasowej w Polsce w latach 1963-1964. Artykuł jest częścią pracy magisterskiej pt. Postać i prezydentura Johna Fitzgeralda Kennedy'ego w świetle prasy polskiej w latach 1960-1964, której fragment opublikowany został w „Studiach Politycznych”.

Cezurę początkową stanowi data zabójstwa prezydenta Kennedy’ego, końcową wyznacza natomiast opublikowanie raportu Komisji Warrena. Artykuł jest rezultatem szerokiej kwerendy. Wśród wykorzystanych tytułów prasowych znalazły się dzienniki ogólnokrajowe: oficjalny organ partyjny - „Trybuna Ludu”, oraz należące do tzw. prasy czytelnikowskiej stołeczne „Życie Warszawy”. W grupie periodyków uwzględnione zostały: „Polityka”, „Tygodnik Powszechny” „Świat” i „Przekrój” oraz wydawane w Stanach Zjednoczonych czasopismo „Ameryka”.

Mimo trwającej w relacjach Wschód-Zachód zimnej wojny, od śmierci Stalina podejmowano wysiłki w celu zmniejszenia napięcia między Stanami Zjednoczonymi a ZSRR. Zorganizowana w lipcu 1955 r., w Genewie konferencja wielkiej czwórki, choć nie doprowadziła do zasadniczych uzgodnień, stanowiła ważki krok w stronę oczyszczenia atmosfery i przełamania wzajemnej wrogości. Szansę na dialog zaprzepaścił jednak incydent z lotem zwiadowczym samolotu U-2, powodując wycofanie się Chruszczowa z zapowiedzianego na maj 1960 r. szczytu w Paryżu.

Stany Zjednoczone pozostawały obiektem nieustannych ataków propagandy komunistycznej. W Polsce największe nasilenie miała ona w okresie stalinowskim. Negatywny obraz USA uległ wyraźnemu przekształceniu dopiero w okresie

\footnotetext{
1 J. Sakowicz, Polityka zagraniczna Stanów Zjednoczonych w okresie prezydentury Johna Fitzgeralda Kennedy'ego na łamach prasy polskiej z lat 1960-1963, „Studia Polityczne” 2005, nr 17, s. $185-237$.
} 
prezydentury Kennedy'ego. Choć nie zaprzestano posługiwania się deformującymi rzeczywistość schematami myślowymi, ostrze propagandy antyamerykańskiej zostało wyraźnie stępione. Kennedy'ego postrzegano jako pozbawionego uprzedzeń polityka młodej generacji, inicjatora polityki odprężenia, którego prezydentura miała szansę otworzyć nowy rozdział w stosunkach Wschód-Zachód. Jego tragiczna śmierć stanowiła wstrząs dla całego świata. Pomimo ideologicznych podziałów poruszyła również opinię publiczną w bloku sowieckim, stawiając jednocześnie pod znakiem zapytania przyszłość relacji amerykańsko-radzieckich i kontynuację dialogu między mocarstwami.

Prezydent Kennedy został zastrzelony 22 listopada 1963 r. podczas wizyty w Dallas w stanie Teksas. Policja aresztowała wkrótce podejrzanego o dokonanie zamachu Lee Harvey'a Oswalda, 24-letniego mieszkańca Dallas, byłego żołnierza marines, pracującego w Teksaskiej Składnicy Podręczników Szkolnych, skąd, jak domniemywano, padły śmiertelne strzały.

Wieść o zamordowaniu prezydenta USA była, jak stwierdził Karol Małcużyński w „Trybunie Ludu”, brutalnym szokiem dla ludzi całego świata, „przyjęto ja ze zdumieniem, oburzeniem, współczuciem". Na łamach prasy polskiej ukazały się fragmenty licznych depesz kondolencyjnych i oświadczeń przywódców całego świata oddających cześć zmarłemu. ,Śmierć J. F. Kennedy'ego jest ciężkim ciosem dla wszystkich ludzi, którym droga jest sprawa pokoju i wspótpracy radziecko-amerykańskiej. (...) Zachowam pamięć o osobistych spotkaniach $z$ prezydentem J. F. Kennedym jako działaczem o szerokich horyzontach, realnie oceniającym sytuację $i$ dążacym do znalezienia dróg rozwiąania problemów międzynarodowych - dzielacych obecnie swiat $-w$ drodze rokowañ" - oznajmił premier ZSRR. Prezydent de Gaulle napisał: „Zginat śmiercia żołnierza pełniac obowiazki w służbie kraju”; Castro zapewnił zaś: „Jako rewolucjoniści nienawidzimy systemu kapitalistycznego i imperialistycznego - ale nie ludzi. Takie czyny jak zamordowanie Kennedy'ego nie znajduja usprawiedliwienia"3.

Przede wszystkim jednak zamach oznaczał wielki wstrząs dla społeczeństwa amerykańskiego. W korespondencji z Nowego Jorku Wiesław Górnicki tak opisywał klimat, jaki zapanował w USA w pierwszym dniu po śmierci Kennedy'ego: „Ameryka nie może otrzqsnać się jeszcze z tej potwornej, niewiarygodnej wieści. Po raz pierwszy od wynalezienia radia $i$ telewizji zamilkty $w$ eterze natarczywe reklamy i muzyka rozrywkowa. (...) Odwołano wszystkie przedstawienia, zawody sportowe, niemal wszystkie imprezy prywatne. W całym kraju ludność samorzutnie wywiesiła flagi opuszczone do pót masztu. Dziś jeszcze, jadąc do biura, widziałem kobiety płaczace na ulicy. Widziałem wystraszone, nie rozumiejące tej grozy dzieci na opustoszałych boiskach. Nowy Jork przypomina miasto wymarte

2 K. Małcużyński, Celnie strzelaja w stanie Teksas, „Trybuna Ludu”, 27 XI 1963, s. 3.

3 O J. F. Kennedym, „Przekrój” 1963, nr 973, s. 1. 
lub dotknięte zaraza. (...) Zgasty światła $w$ dzielnicy rozrywkowej Broadwayu. Gubernator stanu Nowy Jork zarządzit 30-dniowa żałobę. Burmistrz miasta Dallas, miasta, które przejdzie do historii Ameryki, jako miejsce mordu na wielkim synu ziemi amerykańskiej ogłosit solenna żałobę"4.

Byli jednak i tacy - donosił Mieczysław Rakowski w „Polityce” - którzy przyjęli śmierć prezydenta z niekłamanym zadowoleniem: „Kennedy »ponióst śmierć tyrana « - zawołał na zebraniu publicznym $w$ dniu, $w$ którym padły starzały w Dallas - jeden z przywódców ultrareakcyjnej organizacji - »Rady (Białych) Obywateli« w Memphis. Dzieci pewnych szkót w Dallas wyrażały głośno swa radość na wieść o śmierci »kochanka czarnuchów «"s.

Śmierć Kennedy'ego przedstawiano w prasie polskiej jako wynik spisku. „Koalicja południowych rasistów z partii demokratycznej, skrajnie prawicowych republikanów (...), licznych faszystowskich i półfaszystowskich organizacji i grup, wojowniczych militarystów z Pentagonu, najbardziej reakcyjnych odtamów »bigbussinesu« (...) - wszystkie te sity - pisał Stanisław Brodzki w „Świecie” sprzysięgły się, aby odwrócić ster nieśmiało zmierzajacy ku koegzystencji na zewnatrz $i$ bardziej liberalnej polityce na wewnatrz"'. Srodowiska te od lat miały prowadzić przeciwko Kennedy'emu kampanię nienawiści. Podejmowane przez prezydenta próby reform wewnętrznych, zwłaszcza inicjatywy na rzecz praw obywatelskich czy działania zmierzające do osiągnięcia odprężenia międzynarodowego, określane były przez nie jako ,zdrada Ameryki” i „,sprzedaź świata bolszewikom”, sam Kennedy zaś zyskał opinię „,miłośnika Murzynów”, „agenta Moskwy" i ,zwolennika petzającego socjalizmu".

„Twierdza amerykańskiego faszyzmu” był Teksas'. Prasa przypominała, że na parę dni przed planowaną wizytą w Dallas, w lokalnej gazecie „Morning News” pojawiło się płatne ogłoszenie w formie nekrologu dla Kennedy'ego z podpisem „Witaj w Dallas”, pod nim zaś 13 prowokacyjnych i agresywnych pytań do prezydenta $^{9}$. Kolportowano też ulotki stylizowane na listy gończe, opatrzone zdjęciem Kennedy'ego i nagłówkiem „Poszukiwany za popetnienie zdrady”. Prezydent, będąc „,w trakcie przekazywania suwerenności Stanów Zjednoczonych... Organizacji Narodów Zjednoczonych, która wtadaja komuniści”, miał sprzeniewierzyć się konstytucji USA, oraz ,zdradzić przyjaciót' (wśród których wymienieni zostali kontrrewolucjoniści kubańscy, Mose Czombe i Antonio Salazar), okazując jednocześnie przyjaźń wrogom (ZSRR, Jugosławii i Polsce) ${ }^{10}$.

4 W. Górnicki, Cui prodest?, „Życie Warszawy”, 26 XI 1963, s. 2.

5 M. F. Rakowski, A jednak byto to możliwe, „Polityka” 1963, nr 51-51, s. 12.

6 S. Brodzki, W samo południe, „Świat” 1963, nr 48, s. 4-5.

7 K. Małcużyński, Celnie strzelaja...

8 S. Brodzki, W samo...

9 K. Małcużyńki, Celnie strzelają...

10 [Bole]Sław [Wójcicki], Pewna ulotka, „Trybuna Ludu”, 9 XII 1963, s. 6. 
Komentatorzy polscy przyrównywali panującą w USA atmosferę nienawiści do tej, jaka istniała w Polsce międzywojennej, gdy zamordowany został prezydent Gabriel Narutowicz i jednocześnie stawiali pytanie, dlaczego w tych okolicznościach, przed przyjazdem prezydenta do Dallas, nie przedsięwzięto specjalnych środków ostrożności ${ }^{11}$.

Zamach na Kennedy'ego stał się, jak utrzymywała prasa, pretekstem do zorganizowania kampanii antykomunistycznej. „Gdy świat cały przekonany jest, że tylko wśród skrajnych ekstremistów rasizmu i faszyzmu należało szukać sprawcy mordu, znaleźli się tacy, którzy usiłowali skierować swoje zatrute strzały w kierunku ludzi, na których sztandarze dziś w pierwszej kolejności wypisane jest hasło pokojowego wspótistnienia - w kierunku komunistów"12. Analiza życiorysu domniemanego zabójcy, L. H. Oswalda - związków z Komunistyczną Partią USA, działalności w organizacji na rzecz pomocy Kubie, pobytu w Związku Radzieckim i kontaktów z ambasadą ZSRR w USA, jak również znaleziona w jego mieszkaniu literatura marksistowska wskazywały, że Oswald mógł działać na zlecenie obcego rządu. Dziennikarze polscy, kwestionując prawdziwość tejże hipotezy, argumentowali, iż rzecznicy partii komunistycznej i Komitetu Rzetelnego Postępowania wobec Kuby nie potwierdzili członkostwa w nich Oswalda oraz, że po powrocie z ZSRR był on wielokrotnie przesłuchiwany przez FBI. Powątpiewali również, czy morderca pozostawiłby w domu obciążające go materiały. Koronny dowód na winę Oswalda - jego zdjęcie z karabinem typu Mannlicher-Carcano, użytym przez zabójcę prezydenta, z widocznymi na dalszym tle „wywrotowymi” czasopismami „The Worker” i „The Militant”, miał być jaskrawym potwierdzeniem manipulacji dokonywanych przez policję w Dallas. Przyjmowano za niedorzeczne, że domniemany zabójca, na krótko przed popełnieniem zbrodni, miałby sfotografować się z bronią, której zamierzał użyć.

Obiekcje, co do rzetelności miejscowej policji budziły też popełniane przez nią błędy. Wkrótce po aresztowaniu podejrzanego szeryf policji w Dallas miał oświadczyć, że Oswald był członkiem „międzynarodowej konspiracji”, z czego wynikałoby, że prezydent padł ofiarą spisku, jednakże już w parę godzin później, z chwilą wniesienia formalnego oskarżenia przeciw Oswaldowi, podano do wiadomości, że nie miał on wspólników ${ }^{13}$.

Wiele wątpliwości wywołały u polskich komentatorów również okoliczności przesłuchania podejrzanego. „Dlaczego Oswald byt bez przerwy bity $i$ to coraz dotkliwiej? Czy można wykluczyć, że tortury doprowadziły go w pewnym momencie do stanu bliskiego załamania $i$ ze tym się ttumaczy zapowiedź policji, iz wkrótce przyzna się on do winy?” - pytał Daniel Passent w „Polityce”. Zwracał on

11 Zob. S. Brodzki, W samo...; K. Małcużyński, Celnie strzelają...

12 A. K., Gdy trumna była jeszcze na katafalku, „Trybuna Ludu”, 26 XI 1963, s. 2.

13 D. Passent, „Ameryka jest winna światu prawdę...”, „Polityka” 1963, nr 49, s. 8. 
uwagę, iż w trakcie śledztwa Oswald konsekwentnie zaprzeczał stawianym zarzutom, jednak za każdym razem, gdy pokazywano go w telewizji, wyłączano głos. Bulwersujący był również zdaniem dziennikarzy fakt nieuwzględnienia prośby Oswalda o sprowadzenie obrońcy - w trwającym 10 godzin przesłuchaniu nie uczestniczył nikt spoza kręgu policyjnego.

24 listopada Oswalda miano przewieść do więzienia okręgowego. W drodze do furgonetki policyjnej został on śmiertelnie postrzelony. Morderca, Jack Ruby, znany policji właściciel klubów nocnych w Dallas, podejrzewany o kontakty z mafią, przedarł się niezauważony przez kordony policji i wystrzelił z odległości kilkudziesięciu centymetrów. Zabójstwo Oswalda nasunęło szereg nowych pytań. Prasa polska dopatrywała się w nim próby utrącenia śledztwa w sprawie śmierci prezydenta. „Dlaczego z góry zapowiedziano godzinę $i$ trasę przewiezienia Oswalda do więzienia?”, „Dlaczego policjanci dopuścili Ruby'ego do Oswalda na odległość 70 centymetrów?" 14 , „Jak to się stało, że Oswald oskarżony o najgłośniejsze morderstwo polityczne XX wieku przewożony byt w tak niezaradny, nieostrożny sposób?" 15 - dociekano. Dzienniki podały również, że na dwie godziny przed zabójstwem podejrzanego, FBI uprzedziło stanową policję, że planowany jest zamach na Oswalda. Ostrzeżenie to zostało jednak zlekceważone.

Przedstawioną przez policję w Dallas wersję zabójstwa prezydenta podważało - jak donosiła „Trybuna Ludu”, cytując Claude Juliena z „Le Monde” - oświadczenie dr Roberta R. Shawa, dyrektora oddziału chirurgii piersiowej w szpitalu Parkland Memorial, do którego Kennedy został przewieziony tuż po zamachu. Stwierdził on, że jedna z ran wlotowych na ciele prezydenta umiejscowiona była z przodu, oznaczałoby to, że L. H. Oswald, który jak przyjmowała policja, strzelał z budynku składnicy książek - a więc z miejsca znajdującego się z tyłu, za samochodem prezydenta, nie był jedynym zabójcą ${ }^{16}$. Rezultaty, przeprowadzonej w szpitalu wojskowym Bethesda, autopsji zwłok prezydenta nie potwierdziły jednak, jak donosiła „Trybuna Ludu”, konkluzji dr Shawa. Z protokołu oględzin wynikało, że rana z przodu szyi była raną wylotową, spowodowaną drugim, śmiertelnym wystrzałem ${ }^{17}$.

Niejasności i niedopowiedzenia w sprawie zabójstwa Kennedy'ego stanowiły w opinii komentatorów polskich bezsprzeczny dowód prób zamaskowania rzeczywistych winowajców, którymi mieli być reprezentanci skrajnej prawicy.

14 Ibidem, s. 9.

15 K. Małcużyński, Celnie strzelaja...

16 Zbyt wiele mroku i wątpliwości, „Trybuna Ludu”, 16 XII 1963, s. 2. Por. L. Pastusiak, Druga kula, „Polityka” 1992, nr 24, s. 11.

17 Pierwsze pótoficjalne dane o oględzinach zwłok Kennedy’ego, „Trybuna Ludu”, 20 XII 1963, s. 2. Należy zauważyć, że zgodnie z ustaleniami komisji Warrena ranę wylotową na szyi spowodował najprawdopodobniej pierwszy pocisk, który przebił nasadę szyi prezydenta i wyszedł z przodu. Zob. 22 XI 63: Godzina Śmierci, „Ameryka” 1964, nr 74, s. 26 i 27. 
W dwa tygodnie po zabójstwie Kennedy'ego, „Polityka” opublikowała wyniki przeprowadzonej wśród Polaków dziennikarskiej sondy na temat zbrodni w Dallas. Anonimowa ankieta (uczestnicy ujawnili jedynie zawód, wykształcenie i wiek) objęła 170 osób pochodzących z różnych środowisk i miejscowości. Zadano im dwa pytania: 1. Co Pan (Pani) sądzi o okolicznościach zabójstwa prezydenta Kennedy'ego i o aferze w Dallas?; 2. Co doradziłby Pan (Pani) Amerykanom w związku z tymi wydarzeniami? Jakie wyciąga Pan (Pani) w tej kwestii wnioski natury ogólnej?

Respondenci wyrażali głównie żal i współczucie dla narodu amerykańskiego oraz rodziny Kennedy'ego, ale czynili też uwagi na temat wad amerykańskiego systemu władzy: „W kraju, gdzie zamordowano prezydenta i tyle osób pracuje nad tym, aby mordercy pozostali nieznani i nie zostali ukarani nie dzieje się dobrze. Jest to sygnat, ze w USA inaczej wyglada $z$ demokracja $i$ tzw. zgoda narodowa niz to się reklamuje" - oświadczył jeden z ankietowanych. Przeważająca większość respondentów widziała w morderstwie prezydenta ,wynik skomplikowanej gry ciemnych sit politycznych", a blisko połowa, za winną uznawała skrajną prawicę: „Oczywiście to dzieło bojówek faszystowskich i metody faszystowskie szkótka hitlerowska" (inż. mech., 33).

„To zrobili członkowie Ku-Klux-Klanu. Ku-Klux-Klan walczyt z Murzynami $i$ demokratami. Kennedy byt demokratą $i$ chciał równouprawnienia dla czarnych" (kobieta - lekarz dentysta, 57).

„Zabójcy to gangsterzy, ale polityczni z szerokimi wpływami nie tylko w administracji stanowej" (urzędnik Baltony, 38) ${ }^{18}$.

Jerzy Putrament zapamiętał nastrój pierwszych dni po śmierci prezydenta jako niejasny i nerwowy. W swoich wspomnieniach napisał: „Wszystko zdaje sie prowokacja, jakby trzecia runda rozgrywki przeciw Kubie: 1961 rok: inwazja w Zatoce Świń, 1962 - kryzys rakietowy, 1963 - Oswald, klasyczny typ dajacego się manewrować neuropatyka, coś w rodzaju van der Luebbego. W dwa dni potem zabójstwo Oswalda. Cała dramaturgia sprawy wskazuje, że była ona przez kogoś zmajstrowana, ale ten ktoś nie byt bardzo powazny i został osadzony $w$ miejscu przez kogoś silniejszego. Poprzestano na drobnym sukcesie wewnętrznym, usunięciu zbyt liberalnego prezydenta, zrezygnowano z najwyższej stawki" ${ }^{19}$.

$\mathrm{Z}$ tych też względów nie spodziewano się wiele po wynikach śledztwa, powołanej przez prezydenta Lyndona B. Johnsona, specjalnej komisji pod przewodnictwem prezesa Sądu Najwyższego, Earla Warrena. Żaden z jej członków, jak podkreślała „Trybuna Ludu”, nie miał doświadczenia w tego typu sprawach.

\footnotetext{
18 M. Radgowski, M. Turski, Zbrodnia w opinii Polaków, „Polityka” 1963, nr 49, s. 1, 9.

19 J. Putrament, Pót wieku. Natasza, Warszawa 1978, s. 297-298. Najwcześniejsze hipotezy spiskowe przedstawił W. Kostecki w art. Kto zabit Johna Kennedy'ego („Życie Warszawy”, 26-27 XI 1988, s. 7).
} 
Nadto zasadniczym materiałem prac komisji miały być raporty opracowane przez FBI, Tajną Służbę Ochrony Prezydenta i policję z Dallas, co utwierdzało dziennikarzy polskich w przekonaniu, że prawda o zamachu nie zostanie ujawniona ${ }^{20}$.

Opublikowane 24 września 1964 r. sprawozdanie Komisji Warrena podtrzymało przedstawioną przez policję w Dallas wersję zamachu. Komisja stwierdziła, że Oswald działał sam oraz że zabójstwo Kennedy’ego nie było dziełem spisku krajowego ani zagranicznego. Przyjęła, że oddane zostały trzy strzały i że wszystkie one padły z budynku składnicy podręczników. Według jej ustaleń pierwszy pocisk ugodził prezydenta $\mathrm{w}$ kark, wyszedł przodem i trafił w plecy gubernatora Teksasu, Toma Connally'ego; późniejszy, śmiertelny uderzył prezydenta w głowę; trzeci zaś najprawdopodobniej chybił²1.

Polscy komentatorzy odnotowali, że Komisja Warrena odcięła się od wysuwanych przez reakcyjne koła amerykańskie oskarżeń (określanych przez nich jako prowokacyjne), jakoby w sprawę zamordowania prezydenta Kennedy'ego zamieszany był Związek Radziecki. „Poza tym jednak komisja Warrena w swych wnioskach ostatecznie podpisuje się pod wersja policji dallaskiej, która w całej opinii światowej wzbudziła - mówiq̨ najoględniej - jak najdalej idacy sceptycyzm. Tyle tylko, że tę wersję niezwykle obszernie rozbudowuje i obwarowuje góra prawniczych wywodów (...)”22 - pisała „Trybuna Ludu”, przytaczając komentarze prasy zagranicznej, w których sceptycznie odniesiono się do ustaleń komisji. Duński konserwatywny dziennik „Berlingske Tidningen” napisał, że lektura raportu skłania do wniosku, że ,głównym zadaniem komisji nie było ustalenie okoliczności zbrodni w Dallas, lecz obrona amerykańskiego systemu sadowego i prawnego"; waszyngtoński korespondent zachodnioniemieckiej agencji DPA wyraził rozczarowanie sprawozdaniem komisji Warrena, stwierdzając, że choć z prawnego punktu widzenia jest ono poprawne, nie usuwa wątpliwości powstałych na skutek spekulacji na temat zabójstwa; dziennikarz „Le Monde” przyjął z kolei, że raport stanowić może ,gigantyczne fatszerstwo patriotyczne... największq $w$ czasach nowozytnych mistyfikacje rzadowa, obliczona, z przyczyn nie do zbadania, na pogrzebanie zbrodni z 22 listopada ub. roku"23.

Obszerna i szczegółowa analiza wyników śledztwa Komisji Warrena, autorstwa W. Górnickiego opublikowana została na łamach „Polityki”. „Okazuje się, że wszystko to byto proste, tragicznie proste, olśniewajaco proste - komentował Górnicki. Ta sama wersja, jaka pewien szeryf z Teksasu przedstawit zdumionemu światu $w$ ów pamiętny wieczór, została obecnie podniesiona do rangi

\footnotetext{
20 „Trybuna Ludu”, 5 XII 1963, s. 2.

21 Wyjątki ze sprawozdania komisji powotanej do zbadania zabójstwa Prezydenta Kennedy'ego, „Ameryka” 1964, nr 72, s. 58, oraz 22 XI 63: Godzina Śmierci, op. cit., s. 27.

22 B[olesław] W[ójcicki], Jądro ciemności, „Trybuna Ludu”, 1 X 1964, s. 2.

23 Światowe echa raportu Warrena, „Trybuna Ludu”, 30 IX 1964, s. 2.
} 
świętości narodowej; czegoś $w$ rodzaju pomnika aksjomatyki logicznej; powątpiewać moga teraz tylko maniacy lub bluźniercy”. Autor wskazywał, że członkowie komisji to w większości reprezentanci prawicy i establishmentu, a więc ludzie, którzy, jak próbował zasugerować, nie mogli być zainteresowani ujawnieniem kompromitującej prawdy na temat zabójstwa prezydenta. Charakteryzując metodę śledczą, przyjętą przez komisję, wyróżnił cztery podstawowe jej założenia: 1. bezkrytyczne uznanie orzeczeń śledczych FBI - autor zauważał, że zawsze gdy istniała sprzeczność między zeznaniem naocznego świadka a ustaleniami FBI, komisja przychylała się do wersji policji federalnej; 2. pomijanie wszelkich faktów, które mogłyby podważyć pierwotną wersję oficjalną; 3. wybiórcze traktowanie zeznań - zdaniem Górnickiego za wiarygodnych uznawała komisja tych świadków, których zeznania zgadzały się z oficjalną wersją wydarzeń; 4. pomijanie kwestii, które mogłyby odwrócić uwagę komisji od zasadniczego przedmiotu dochodzenia - komisja nie uwzględniła szeregu istotnych (zdaniem autora) kwestii, zasłaniając się twierdzeniem, iż pozostawało to w luźnym związku z głównym nurtem śledztwa. Raport komisji Warrena nie przyczynił się, w opinii Górnickiego, do rozstrzygnięcia wątpliwości i niejasności wokół zamachu z 22 listopada. Autor stwierdzał jednak: „Jeżeli ta »cała prawda « wystarczy Amerykanom i nie budzi w nich niepokoju moralnego, nie ma żadnych racjonalnych powodów, abyśmy się mieli bawić $w$ domorostych detektywów. Ostatecznie w konkurencji z FBI nikt wygrać nie może, a naszych watpliwości, jakkolwiek by byty poważne, nie możemy poprzeć dowodami. Między innymi dlatego trzeba raport Warrena uznać za jedno z największych, pomnikowych osiagnięć amerykańskiej cywilizacji i kultury, mentalności i logiki użytkowej. Z tym dokumentem na serio polemizować nie sposób. Trzeba się nauczyć z nim wspótistnieç”24.

Zabójstwo Kennedy'ego zrodziło obawy o losy osiągniętego z trudem odprężenia w relacjach Wschód - Zachód: „Pierwsze pytanie, jakie (...) narzuciła i politykom i tzw. człowiekowi z ulicy tragiczna śmierć, można by było sformułować następująco: czy linia Kennedy'ego, która niezależnie od okresowych zygzaków, była zasadniczo linia rokowań $i$ realistycznego poszukiwania rozsadnych $i$ niezbędnych w epoce termojądrowej uzgodnień i porozumień, będzie $w$ Waszyngtonie utrzymana?”. „Trybuna Ludu” przytaczała opinie agencji i dzienników zachodnich (podkreślano, że nie uwzględniono czasopism lewicowych), które oceniały, iż śmierć prezydenta USA ,wnosi do polityki światowej element niepokoju i niepewności” („Neue Rhein Zeitung”). Głosy te miały dowodzić, że „polityka rokowań $i$ odprężenia międzynarodowego oraz pierwsze sukcesy polityki pokojowego wspótistnienia (...), stały się również dla społeczeństwa krajów kapitalistycznych wartościa niezwykle (...)"25.

24 W. Górnicki, Cała prawda?, „Polityka” 1964, nr 41, s. 13, 14, 16.

25 B[olesław] W[ójcicki], To co najważniejsze, „Trybuna Ludu”, 28 XI 1963, s. 1. 
Szukając przyczyn niemającej precedensu reakcji opinii publicznej całego świata na śmierć prezydenta USA, stwierdzano, że nie da się jej objaśnić ani urokiem, ani popularnością zmarłego, ani też znaczeniem jego urzędu czy potęgi Stanów Zjednoczonych. „Wyjaśnienia upatrywać należy - pisał Ludwik Dembiński w „Tygodniku Powszechnym” - raczej w fakcie, że John Kennedy stat się $w$ polityce amerykańskiej symbolem pragmatyzmu i optymizmu, dązenia do pokoju $i$ wreszcie wiary $w$ wolność $i$ równość wszystkich ludzi”. Liczny udział Amerykanów w uroczystościach pogrzebowych i atmosfera prawdziwej żałoby, jaka zapanowała w USA, miały dowodzić, że naród amerykański głęboko przeżył tę stratę i stanowić swego rodzaju rehabilitację dokonań prezydenta. „Niewątpliwie znaczna część społeczeństwa amerykańskiego nie zgadzała się z polityka prezydenta Kennedy'ego i stąd wynikały trudności, z jakimi walczyly w Kongresie jego inicjatywy ustawodawcze. Na pewno szereg krytyk wypowiedzianych pod adresem jego administracji byto uzasadnionych. Ale z chwila jego śmierci społeczeństwo zrozumiało, że zrobit bardzo dużo". Powszechnie wyrażany żal i rozpacz po śmierci prezydenta nie zwalniały jednak, w ocenie Dembińskiego społeczeństwa amerykańskiego z odpowiedzialności za tę tragedię: „Ameryka nie może uchylić się od odpowiedzialności za akt mieszczacy się przecież $w$ jakimś nurcie w jej tradycji, choćby tylko ubocznym. Poczucie odpowiedzialności będzie tym cięższe, że ten akt gwałtu politycznego rzuca cień na hasła głoszone przez Stany Zjednoczone $w$ warunkach konfliktu ideologii" ${ }^{26}$.

Dokonana zbrodnia skłaniała do rozważań nad tkwiącymi w systemie amerykańskiej demokracji anomaliami i panującym w społeczeństwie USA kryzysem moralnym. Ten rodzaj refleksji stanowił rezonans zapoczątkowanej w Stanach Zjednoczonych debaty, której istota zawierała się w pytaniu, czy morderstwo prezydenta stanowiło odizolowany wypadek, czy też było wyrazem niedojrzałości politycznej Amerykanów? ${ }^{27}$. Cytowany przez D. Passenta James Reston napisał w „New York Times”: „Coś w tym narodzie, jakiś rys szaleństwa i gwałtu zniszczył najwyższy symbol prawa i ładu... Nawet Waszyngton, dla którego brutalność jest chlebem powszednim, nie mógł myśleć o politycznych skutkach morderstwa", a „St. Louis Post Dispatch” zapytywał: „Co się dzieje ze Stanami Zjednoczonymi, ze istnieje klimat dla takiego wyczynu?”, dodając: „Nasza demokracja znajduje się $w$ niebezpieczeństwie" 28 .

Dziennikarze polscy w odpowiedzi na te pytania stawiali diagnozę, która przyczyn tego stanu rzeczy upatrywała w ,schorzeniu wewnętrznym” Ameryki. Jego objawem miało być ,istnienie w USA takich sprzecznych zjawisk, jak ultranowoczesna technika, a średniowieczny ruch Bircha, hasła wolności a rasizm,

\footnotetext{
26 L. Dembiński, Nowa granica, „Tygodnik Powszechny” 1963, nr 49, s. 2.

27 J. A. Henretta, W. E. Brownlee, D. Brody, S. Ware, M. S. Johnson, America's History, 3rd ed., New York 1997, s. 933.
}

28 D. Passent, Ameryka... 
niechęć społeczeństwa do wojny a koszmarne zbrojenia, praktyczny realizm oraz racjonalistyczny sposób myślenia przeciętnego Amerykanina i równocześnie przejawy psychozy nienawiści do postępu, brak jakichkolwiek istotnych różnic między obu partiami a zaciekła walka między nimi, władza federalna a rzady stanowe"29. Zamach na prezydenta miał zatem dowodzić, że ideały amerykańskiej demokracji, ideały pierwszych Amerykanów uległy dewaluacji, stały się, jak obrazowo przedstawiał to redaktor „Polityki”, „relikwiami, tak jak konne wozy pionierów, ciagnacych niegdyś z uporem $w$ gtąb kontynentu a dziś spoczywajace w muzeach". Rakowski wyrażał jednak nadzieję, że tragiczna śmierć Kennedy'ego będzie początkiem ,pryncypialnej walki z tym wszystkim, co pograża ten naród $w$ anarchii $i$ konserwatyzmie, co budzi zdumienie, niechęć a nawet odraze wśród ludów, co napawa lękiem narody pragnące pokoju"30.

W podobnej tonacji wypowiadał się w „Życiu Warszawy” J. Putrament: „Choroba dallasowska nie jest nieuleczalna, faktem jest jednak, że usunać ja może tylko bardzo energiczna kuracja. Chcemy wierzyć, że tej energii nie zabraknie następcom Johna Kennedy'ego. Zdrowa Ameryka potrzebna jest nie tylko Amerykanom. Wszyscy na kuli ziemskiej jesteśmy tym zainteresowani (...)"31.

Tego optymizmu nie podzielał natomiast Stanisław Brodzki. Źródeł tragedii poszukiwał on znacznie głębiej, bo w samych początkach historii Ameryki. Zaznaczał, że Kennedy był już czwartym (po Abrahamie Lincolnie, Jamesie A. Garfieldzie i Williamie McKinley'u) prezydentem USA, który zginął z rąk zamachowca. Ta ponura statystyka świadczyć miała o ,historycznie uwarunkowanym nagromadzeniu nienawiści i fanatyzmu, który w prostej linii od palenia czarownic $w$ Salem $i$ wymordowania Indian, poprzez lynche $i$ Ku Klux Klany, poprzez maccarthyzm i komisje badania działalności nieamerykańskiej, poprzez najkrwawsze $w$ dziejach rozgramianie strajków przy pomocy prywatnej policji »Pinkertonów « $i$ zorganizowana $w$ (...) gangach przestępczość, poprzez wysadzanie $w$ powietrze murzyńskich dzieci $w$ kościołach - wiedzie do zamordowania prezydenta i usunięcia później jego domniemanego zabójcy"32.

W prasowej debacie na temat konsekwencji i odpowiedzialności za śmierć prezydenta, pojawił się wszakże inny głos, który w popełnionej zbrodni widział nie kryzys moralny społeczeństwa amerykańskiego, lecz dramat całej cywilizacji. Antoni Gołubiew pisał w „Tygodniku Powszechnym”: „Mord ten jest zbrodniq naszych czasów, okazat się możliwy w naszej cywilizacji, stanowi nasza sprawę, jest na s a klęska, jest ciosem zadanym na m, to znaczy ludziom, którzy na catym świecie naleza do jednego stronnictwa: tego, co daży do pokoju, do rozwiq-

29 M. Hofman, Z teki kronikarza, „Polityka” 1963, nr 48, s. 9.

30 M. F. Rakowski, A jednak...

31 J. Putrament, Choroba z Dallas, „Życie Warszawy”, 28 XI 1963, s. 3.

32 S. Brodzki, W samo..., s. 4. 
zywania spraw międzynarodowych na drodze kompromisu $i$ wzajemnych ustępstw, które pragnie równości wszystkich ludzi, walczy przeciw wszelkiej segregacji i niewoli. Kennedy byt jednym z nas [podkr. w oryginale - J. S.] (...)"33.

Pozamachowa kampania prasowa w Polsce, mimo iż względnie krótkotrwała, była bardzo intensywna. Liczba ukazujących się artykułów oraz drobiazgowa analiza ustaleń śledztwa policyjnego i powołanej przez L. B. Johnsona, specjalnej komisji pod przewodnictwem Earla Warrena badającej okoliczności śmierci prezydenta, wskazują jednoznacznie, uwzględniając nawet istniejącą cenzurę, na ogromne zainteresowanie i poruszenie sprawą zamachu w ówczesnej Polsce.

Przyjęta przez prasę polską hipoteza dotycząca motywów zabójstwa zakładała istnienie spisku politycznego. Obierając w polityce międzynarodowej zbyt liberalny kurs, prezydent miał narazić się nastawionym wojowniczo ultraprawicowym kołom Waszyngtonu. Zamach na Kennedy'ego stanowił zatem, w opinii polskich komentatorów, kolejną odsłonę zimnej wojny. Podkreślanie prokomunistycznych sympatii domniemanego zabójcy, L. H. Oswalda służyć miało, w przekonaniu dziennikarzy, uruchomieniu antykomunistycznej histerii i rozpętaniu nagonki przeciwko komunistom. Wersję spisku politycznego dziennikarze starali się uwiarygodnić wskazując na celową niedbałość prowadzących śledztwo, jak też wysokie prawdopodobieństwo sfabrykowania przez nich dowodów.

Prasa polska podkreślała również, że zabójstwo prezydenta nie było jednostkowym wypadkiem, lecz kolejnym z czarnej serii mordów politycznych, co miało świadczyć o niedojrzałości politycznej Amerykanów oraz podważać ideały amerykańskiej demokracji. Zamach na prezydenta Kennedy’ego był niezaprzeczalnie wstrząsającym wydarzeniem dla całego świata, jednak w warunkach wojny ideologicznej, szybko stał się propagandowym orężem, stanowiąc dowód słabości systemu kapitalistycznego i niemoralności amerykańskiego społeczeństwa.

\section{The Kennedy Assassination in Polish Press}

The aim of the article is to present the reception of the Kennedy assassination in Poland in 1963-1964. The Kennedy assassination was undoubtedly a great shock for the people all over the world, however, in terms of the ideological war, it quickly became a propaganda means to prove the weakness of the democratic system and the immorality of the American society. The Polish press underlined the fact that the murder of President Kennedy was not an isolated act, but consecutively the fourth political murder in the history of the United States. The Warren Commission's findings were not recognized as persuasive.

33 A. Gołubiew, Przykład Afryki, „Tygodnik Powszechny” 1963, nr 51-52, s. 2. 
According to the theory assumed by the Polish press, the conspiracy of the Cold Warrior faction was behind the president's assassination, who was perceived as too liberal and willing to compromise with the Soviet Union. The Polish press also pointed out that Kennedy's assassination had become a pretext to organize the anticommunist campaign. 